\title{
Social and economic values chain assessment of key non-timber forest products around Mbam and Djerem National Park's ecoregion of Cameroon: Case of Xylopia aethiopica, Beilschmiedia anacardioides and Beilschmiedia jacques-felixii
}

\author{
Souare Konsala ${ }^{1^{\star}}$, Fotso Roger-Corneille ${ }^{2}$, Froumsia Moksia ${ }^{1}$, Todou Gilbert ${ }^{1}$, \\ Ibrahima Adamou ${ }^{3}$ and Mapongmetsem Pierre-Marie ${ }^{3}$ \\ ${ }^{1}$ Department of Biological Sciences, Faculty of Science, University of Maroua, P. O. Box 814 Maroua, Cameroon.
${ }^{2}$ Wildlife Conservation Society, P. O. Box 3055 Messa, Yaoundé, Cameroon.
${ }^{3}$ Department of Biological Sciences, Faculty of Science, University of Ngaoundéré, P. O. Box 454, Ngaoundéré,
} Cameroon.

Received 19 July, 2019; Accepted 6 January, 2020

The periphery of Mbam and Djerem National Park in Cameroon harbors valuable forest resources including key non-timber forest products (NTFPs) that contribute to sustain livelihood of many people in terms of consumption and income generation. However, poor studies have been carried out to assess the socio-economic importance of the value chain of key NTFPs, threats on resources and implication for trade development. We used the value chain analysis approach to map and assess the socio-economic importance of the value chain of three key NTFPs such as Xylopia aethiopica, Beilschmiedia anacardioides and Beilschmiedia jacques-felixii, from forest to market place. The results of the study showed that interesting parts of the plants are the fruits that are harvested and processed for sale or local consumption. Annual profit margins for 17 producers of $B$. anacardioides and $B$. jacques-felixiiare was estimated at 1,196,188 FCFA (2023.45 USD) representing 68\%, and for 52 producers of $X$. aethiopica was estimated at 31,280,000 FCFA (52912.57 USD) accounting for $85 \%$. This constitutes an important contribution to the total income of producers of these NTFPs across the region. Profit margins of wholesalers are more important than that of producers and can be classified as follows: 11 wholesaler's of $B$. anacardioides and $B$. jacques-felixii, 1,908,937 FCFA (3229.12 USD) representing $75 \%$ (t-test, $\mathrm{df}=26 ; \mathrm{p}=0.0004)$; and 20 wholesalers of $X$. aethiopica, 51,888,000 FCFA (87772.61 USD) representing $94 \%$ (t-test, $d f=70 ; p=0.0009$ ). The exploitation of $X$. aethiopica is practiced by felling the trees and the species recorded a high vulnerable index $(V I=2.61)$. This practice jeopardizes the natural regeneration of the species in the undergrowth and alters the structure and floristic composition of the plant communities. In the north-eastern part of the park, local people manage the existing species through enrichment plantings.

Key words: Values, plant species, products, park, Cameroon.

\section{INTRODUCTION}

Millions of rural and urban dwellers across the world make use of a wide diversity of forest products, including timber and non-timber forest products, to fulfill their livelihood requirements. Such forest products are 
gathered for household consumption, to generate cash income, and as a fall back in times of emergency or a means to income diversification. All these roles are significant, and often, non-timber forest products (NTFPs) perform multiple functions simultaneously (Shackleton et al., 2011). NTFP trade development required mapping of actors engaged along the trade, from forest to market places, and exports. This approach is termed by some actors as value chain analysis assessment, and aims at examining the full range of activities that are required to bring a product in a particular enterprise from its conception to its end markets.

As NTFPs become increasingly important commercially, local efforts to take advantage of the opportunities they present can be complicated by value chain development context and environment. In remote forest areas, as in mountain regions, markets in general are underdeveloped, and even in more developed regions monopoly buyers and sellers are well established and discourage the emergence of small-scale enterprises (Scherr et al., 2003). NTFPs produced in remote areas are sold through a long marketing channel which is inefficient and does not provide a fair share of the profits to collectors of the products. Karki and Bhattarai (2006) reported that producers and collectors of NTFPs in general receive between 15 and $20 \%$ of the final value of the products in the market chain. In the case studies from sub-Saharan Africa, most of the NTFPs contribute less than $50 \%$ to household incomes and in nine cases, less than $25 \%$. In only three cases, NTFPs, especially in Cameroon, contribute more than $70 \%$ to household incomes, namely Prunus africana, Gnetum spp. and Irvingia sp. (Awono et al., 2002a; Sunderland and Ndoye, 2004; Endamana et al., 2016; Muhammad et al., 2017).

Timko et al. (2010) noted that in Africa, over two-thirds of the continent's 600 million people are estimated to rely on forest products, either in the form of subsistence uses or as cash income derived from a wide range of timber and non-timber forest products (NTFPs). There is a significant long regional trade in NTFPs amongst other Central Africa countries in some products such as Gnetum africanum, Gnetum buchholzianum, Irvingia gabonensis, Irvingia wombolu, Baillonella toxisperma, Cola acuminate and Cola nitida. However, for many NTFPs, the social and economic values and quantities harvested and traded are not assessed in a precise manner (Wasseige et al., 2009) and threats affecting the value chain are poorly known, especially for trade development.

It is widely acknowledged that forests and NTFPs play a key role in the daily life of millions of people living in rural areas in Cameroon (Cosyns et al. , 2011; Awono et al., 2016).

The Cameroonian 1994 Forestry Law identifies and sets out controls for special forest products, many of which are NTFPs. However, it does not define NTFPs nor is there an explicit logic in the selection of products or prioritization of NTFPs to enable sustainable management or monitoring. Ingram and Schure (2010) identified 45 NTFPs as priority or key meaning that they were attributed the highest values based on the level of consumption, extent and volume of trade, multiple uses of species and use of multiple parts of a species and the level of vulnerability. Data concerning actors involved in such NTFPs value chain, harvested, consumed, processed and traded amounts as well as gross and net mean revenues generated are poorly known around Mbam and Djerem National Park's ecoregion in Cameroon, especially for trade development and management. Apart from Arabic gum that is well-known, the northern part of Cameroon is not well represented on terms of NTFPs production (Awono et al., 2016).Xylopia aethiopica, Beilschmiedia anacardioides and Beilschmiedia jacques-felixii which are key NTFPs widely distributed in the ecoregion of Mbam and Djerem National Park situated in the northern part of Cameroon are little known in terms of volumes, values and sustainable management. They are mostly collected by local communities at the periphery of the protected area. Souare et al. (2012) have shown that the mean number of stems cut for harvesting these products was 15.5 \pm 5.5 stems/ha in the disturbed sites. Since the key NTFPs are more available inside the Park and the buffer zone and given the fact that there isno any exploitation permit, conflicts between communities and forestry agents are very tough. The study was conducted specifically to:

i) examine the local uses of $X$. aethiopica, $B$. anacardioides and $B$. jacques-felixii around the Mbam and Djerem National Park's ecoregion;

ii) assess the economic values of the three key NTFPSalong the value chain from forest to market places;

iii) assess the vulnerability status of such key NTFPs species around the Mbam and Djerem National Park's ecoregion.

\section{MATERIALS AND METHODS}

\section{Study site}

The study was carried out at the catchment of Mbam and Djerem National Park in Cameroon. The park covers an area of 416512 ha which is one of the highest protected area in Cameroon after the Dja Biosphere Reserve which covers 526,000 ha. It lies between $5^{\circ} 30^{\prime}$ to $6^{\circ} 13^{\prime} \mathrm{N}$ and $12^{\circ} 23^{\prime}$ to $13^{\circ} 10^{\prime} \mathrm{E}$ at the northern limits of the

${ }^{*}$ Corresponding author. Email: konsala.souare@fs.univ-maroua.cm. Tel: +237 696447965.

Author(s) agree that this article remain permanently open access under the terms of the Creative Commons Attribution License 4.0 International License 


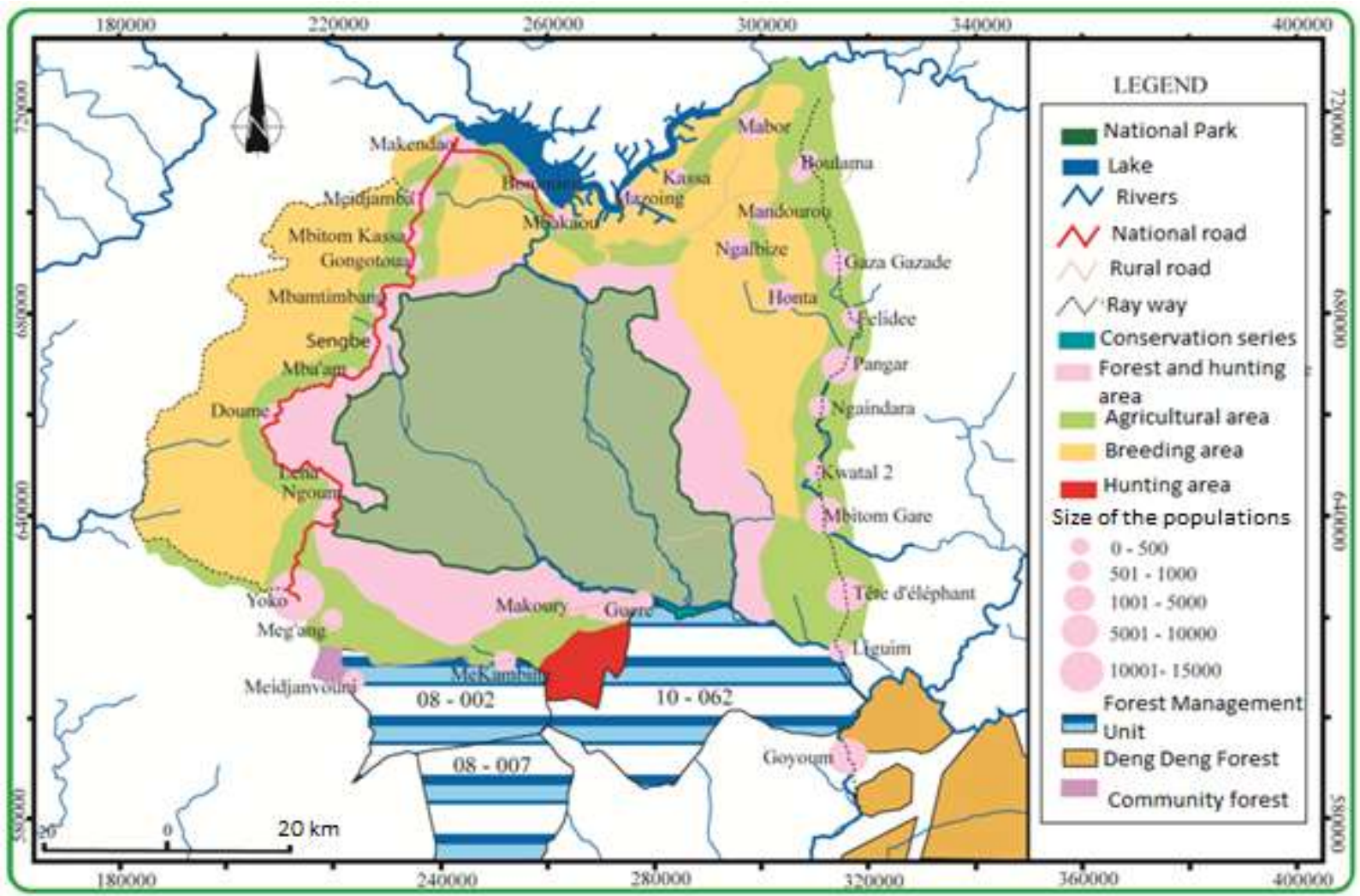

Figure 1. Map of location of the study site (adapted from the management plan of the park).

Congo Basin rainforest, in the Sudano-Guinean zone. Statistics indicated by Souare (2015) showed that about 28694 inhabitants for 74 villages live at the immediate periphery of the Park. The land reserved for agriculture, livestock, hunting and the collection of forest timber products and non-timber forest products covers an area of $1,148,170.887$ ha (Figure 1).The geological substratum consists of a series of gneiss and undifferentiated granites. The study site is characterized by two seasons: the wet season that extends from April to November and the dry season occurs from December to March (Souare, 2015). The mean annual precipitation is $1765.52 \pm 214.17 \mathrm{~mm}$, with a mean monthly temperature ranging from 22.2 to $27.7^{\circ} \mathrm{C}$. The wettest months are from June to October (Figure 2). The hydrography of the area consists of many rivers: rivers flowing on rocky beds, small waterfalls and the great River Djerem. The main vegetation type consists of semi-deciduous forest, gallery forest and savannas (Letouzey, 1985). Most of the people who live at the periphery of the park rely solely on agriculture, livestock and forest resources to meet their basic needs. Non-timber forest products exploitation has been extensive in some areas, mainly in the northern and eastern part of the park. Since key NTFPs are more available inside the Park and the buffer zone, local communities sometimes make incursions in these zones. This situation is causing conflicts between the local communities and the ecoguards.

\section{Data collection and analysis}

\section{Local uses and assessment of key NTFPs production}

Local uses and production assessment were conducted in 11 villages at the periphery of the park. They were selected on the basis of the size of the population, the number of actors involved in the sector (producers, traders, buyers) and the importance of the market (availability of products in the market). Beside a total of 69 collectors of key NTFPs, with 17 producers of $B$. anacardioides and $B$. jacques-felixii along with 52 producers of $X$. aethiopica, participatory rural appraisal developed by David-Case (1990) was performed in order to appreciate their local uses. Among the 69 producers, there was no woman since harvesting is mostly done by felling the trees and then needs a lot of physical effort. For each harvester, a sheet or book of accounts was given and filled accordingly, and local uses of plant organs were acknowledged. The monitoring and collection of the information available on the sheets occurred every two to three weeks throughout the production period. The information collected related to the type of container, quantities harvested, consumed and sold, the costs (handling fees, storage, transport, communal taxes, custom taxes, forest agents) and profit margins. Quantities were measured with a balance. Other information concerned the places of harvest, the distance from the village and the abundance of resource species in the harvesting sites.

\section{Market study and economic values of key NTFPs at the periphery of Mbam and Djerem National Park}

A market study was carried out among the actors involved in the market chains of the key NTFPs at the periphery of the Mbam and Djerem National Park. The actors were 31 traders including semiwholesalers, wholesalers and retailers. Only one female wholesaler was found among the 31 and concerned $B$. anacardioides and $B$. jacques-felixii. All the retailers found in the markets were women. The study considered the accessibility of markets and role they play 


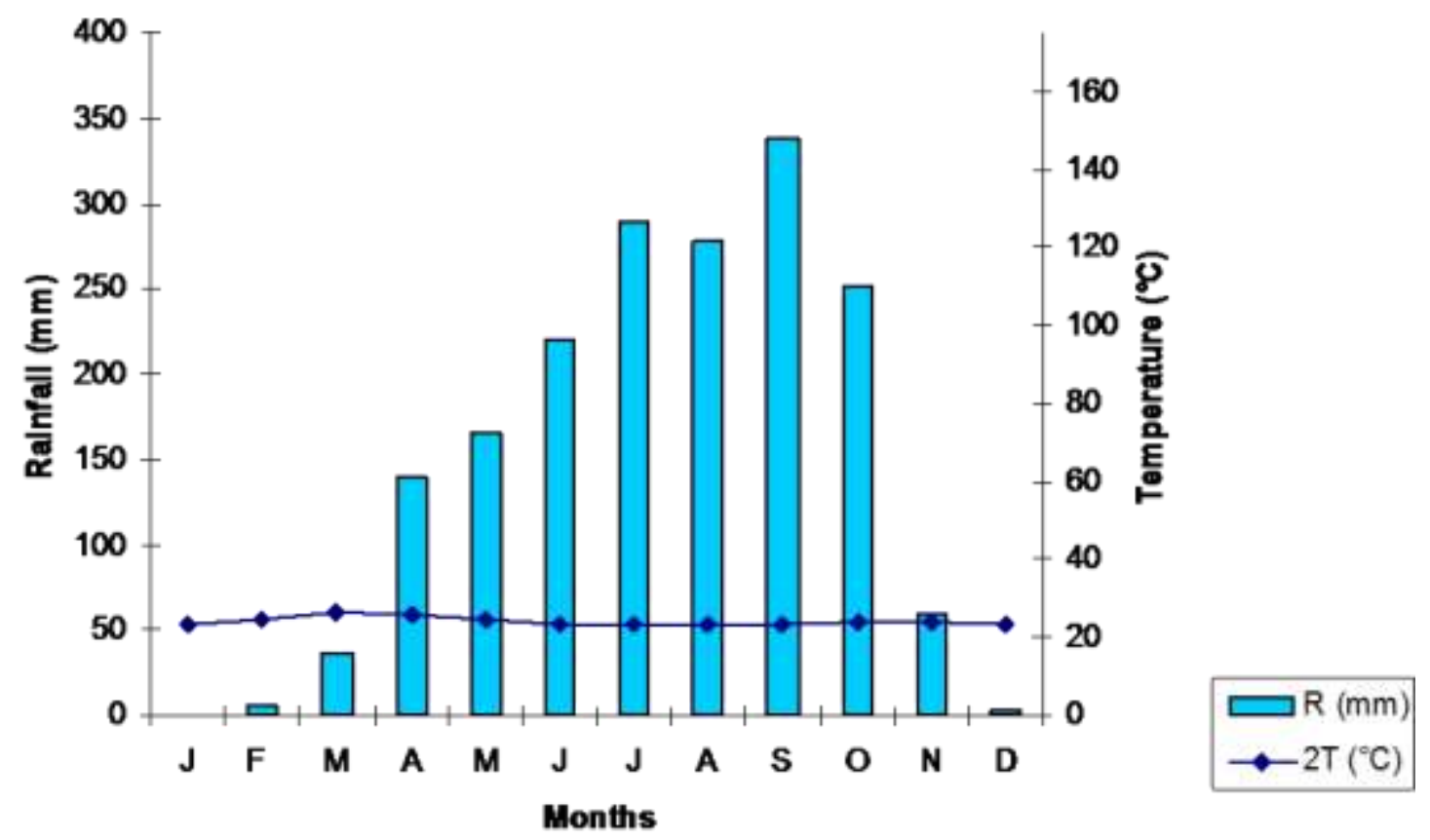

Figure 2. Ombrothermal diagram of the area (Hydroelectric Dam of Mbakaou, Adamawa Region).

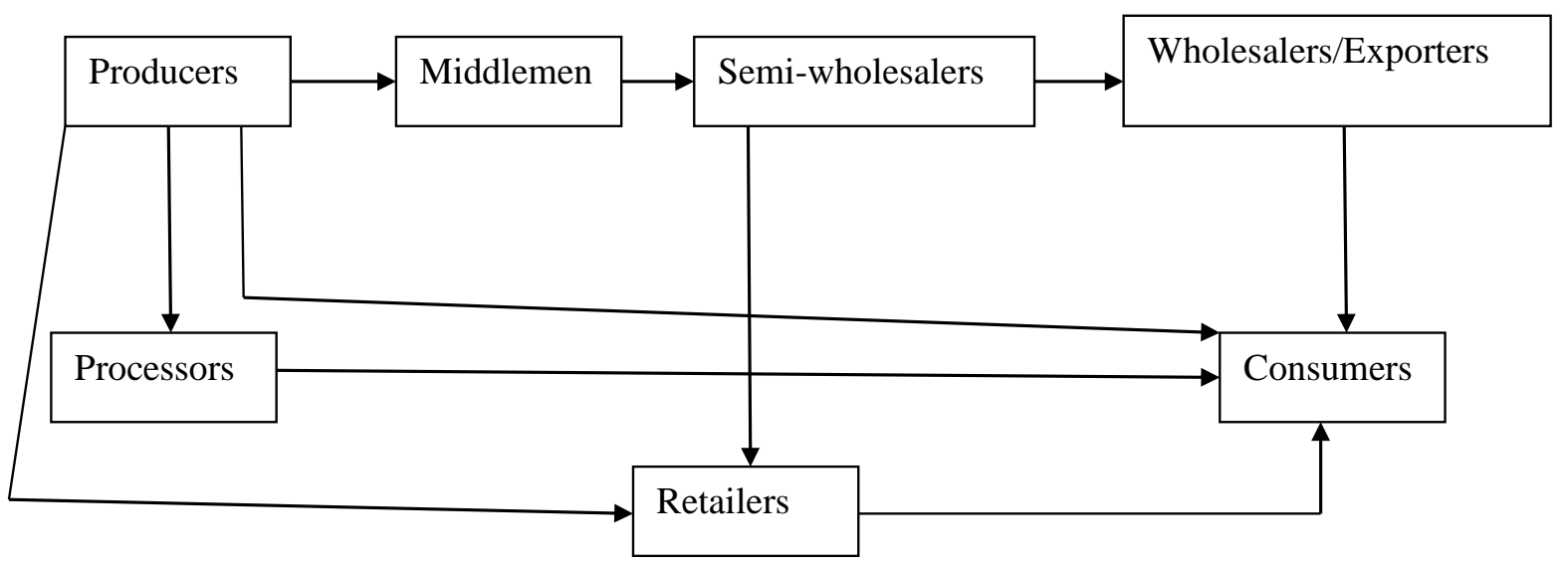

Figure 3. Key NTFPs market value chain at the periphery of Mbam and Djerem National Park. Source: Adapted from Awono et al. (2016).

in the concentration and distribution of key NTFPs, their links with other markets and neighboring countries.Ten (10) local markets were chosen and completed by thirteen (13) railway stations.An accounting sheet was given to each actor to be filled after an activity, mainly semi-wholesalers and wholesalers. The information concerned the quantities of key NTFPs purchased and sold, the dates and places of purchase and sale, processing and packaging, costs, trade margins and the number of traders involved.

According to Awono et al. (2016), in the context of free economy in Cameroon, economic value of a good is the maximum amount a buyer is willing to pay or has paid for it. The economic value considered in this paper is the financial value of the quantities of key NTFPs sold. Also, the rate of key NTFPs destined for selfconsumption is estimated. The market value chain considered in this paper was already developed by Awono et al. (2016) (Figure 3 ). Only middlemen do not own capital but act on behalf of semi- wholesalers and wholesalers.

The profit margins of the collectors were calculated according to the general pattern (Fuashi et al. 2011):

$\mathrm{PM}=\mathrm{SP}-\mathrm{TC}$

where $\mathrm{PM}=$ Profit margins of collectors; $\mathrm{SP}=$ Sale price; $\mathrm{TC}=$ Total costs.

The following formula was used to calculate the profit margins of the traders:

$\mathrm{PMW}=\mathrm{SP}-(\mathrm{PP}+\mathrm{TCC})$

where $\mathrm{PMW}=$ profit margins of the Wholesalers; SP = sale price; $\mathrm{PP}=$ purchase price; $\mathrm{TCC}=$ total costs of the commercialization. 
Table 1. Important parameters for vulnerable index (VI).

\begin{tabular}{llll}
\hline \multirow{2}{*}{ Parameter } & \multicolumn{3}{c}{ Vulnerability to an uncontrolled exploitation } \\
\cline { 2 - 4 } & Weak (scale = 1) & Moderate (scale = 2) & High (scale = 3) \\
\hline Frequency of use (FU) & $\mathrm{FU} \leq 20 \%$ & $20 \% \leq \mathrm{FU} \leq 60 \%$ & $\mathrm{FU} \geq 60 \%$ \\
Number of uses (NU) & $\mathrm{NU}<2$ & $2<\mathrm{NU}<4$ & $\mathrm{NU}>5$ \\
Organ of plant used (OPU) & Leave, latex & Fruit, branch & Wood, seed, bark, root, flower \\
Method of collection (MC) & Picking & - & Picking, logging \\
Stage of development (SD) & Old or senescent & Adult & Young \\
Relative frequency (Fr) & $\mathrm{Fr} \geq 2 / 3 \mathrm{Fm}$ & $1 / 3 \mathrm{Fm} \leq \mathrm{Fr} \leq 2 / 3$ & $\mathrm{Fr} \leq 1 / 3 \mathrm{Fm}$ \\
\hline
\end{tabular}

$\mathrm{Fm}=$ maximal relative frequency.

Source: Adapted from Betti (2001).

The t-test was used to establish the average differences between producers and wholesalers.

\section{Assessment of vulnerability status of the three key NTFPs}

The vulnerability status was assessed through 69 actors' perceptions involved in the production of the three key NTFPs. The following questions were asked: collected organs, domains of the use, mode of collection, stage of development of the organ, the interviewee's point of view on the state of abundance of the species, the possible causes of the scarcity of plant resources and proposals for strategies for the conservation of useful species. The three-level vulnerability scale, from 1 to 3, proposed by Betti (2001), was used to calculate species vulnerability: 1 for species with weak vulnerability; 2 for species with moderate vulnerability; and 3 for a high vulnerable species (Table 1). The vulnerability index of the species (Vli) was calculated from the following formula (Betti, 2001):

$\mathrm{Vli}=\mathrm{N} / 6$ with $\mathrm{N}=\mathrm{N} 1+\mathrm{N} 2+\mathrm{N} 3+\mathrm{N} 4+\mathrm{N} 5+\mathrm{N} 6 ; \mathrm{N} 1=$ frequency of use; N2 = Number of uses; N3 = organ of plant used; N4 = method of collection; N5 = stage of development; N6 = relative frequency. $\mathrm{Vli}<2$, the species is weakly vulnerable; $2 \leq \mathrm{Vli}<2.5$, the species is moderately vulnerable;

$\mathrm{Vli} \geq 2.5$, the species is highly vulnerable.

\section{RESULTS}

\section{Local uses of resource species}

The resource species are sought either for their reproductive organs notably fruits and seeds,or for their vegetative organs constituted ofstems and leaves. As such, they are grouped intotwo categories namely reproductive organs and plant structures (Table 2).

$X$. aethiopicais mainly used by forest dwellers for its fruits as seasoning. They are added to some drinks such as milk, coffee and porridge, and are considered as real tonic both for man and woman. These fruits are also used in traditional pharmacopoeia to treat toothache, rheumatism, herpes and asthma. In cross-border areas, namely Chad, Libya, Sudan and Nigeria where the product is exported, it is used in the manufacture of perfume according to some foreign traders thatwe encountered. Furthermore, the stem of $X$. aethiopica is used as pole for the construction of roof. The wood is hard, resistant to rot and animal parasites, especially termites. The leaves are consumed raw or cooked as vegetable by the local people.

$B$. anacardioides and $B$. jacques-felixii are used for their fruits and seeds as seasoning and thickening of sauce. The seeds transformed into powder serve in preparation of maize fritters. The sauce prepared with the powder is recommended to pregnant women in order to facilitate childbirth.

\section{Economic value and contribution to the households}

Fruits of $X$. aethiopica, B. anacardioides and $B$. jacquesfelixii are collected from forest galleries and mosaic forest-savanna by local people at the periphery of Mbam and Djerem National Park. Collectors are mainly constituted of men since the exploitation by felling systematically the trees need a lot of physical effort. Theysell their products to middlemen, semi-wholesalers or wholesalers. The commercialization channel of these products goes beyond the sphere of the park. The fruits of $X$. aethiopica are sold to foreigners who come from Chad, Sudan, Nigeria and Libya and constitute the wholesalers. The fruits of $B$. anacardioides and $B$. jacques-felixii are sold to semi-wholesalers living in the villages and wholesalers coming from other regions of the country. These wholesalers resell the products expensive to retailers during shortage period.To avoid post-harvest losses, fruits of $X$. aethiopica are dried with fire and then spread to the sun before being packaged. Also, fruits of $B$. anacardioides and $B$. jacques-felixii are boiled, dried and packaged in bags before being sold in regional and/or national markets (Figure 4).

The estimated quantity of $X$. aethiopica collected was 172.96 tons for six months of exploitation and both for $B$. anacardioides and $B$. jacques-felixii 2.513 tons for five months of exploitation (Table 3 ). The sale values obtained from $X$. aethiopica appear to be the most important, reaching $36,800,000$ FCFA for 52 collectors and $55,200,000$ FCFA for 20 wholesalers. Production 
Table 2. Various uses of NTFPs according to actors engaged in the value chain.

\begin{tabular}{|c|c|c|c|}
\hline Species & $\begin{array}{l}\text { Categories of } \\
\text { product }\end{array}$ & $\begin{array}{l}\text { Collected } \\
\text { organs }\end{array}$ & Local uses \\
\hline $\begin{array}{l}\text { Xylopia aethiopica A. Rich., Beilschmiedia anacardioidesRob. \& Wilcz., } \\
\text { Beilschmiedia jacques-felixiiRob. \& Wilcz. }\end{array}$ & $\begin{array}{l}\text { Reproductive } \\
\text { organs }\end{array}$ & Fruits & $\begin{array}{l}\text { Traditional pharmacopoeia }{ }^{a} \text {, tonic }{ }^{a} \text {, } \\
\text { perfume }^{a} \text { Foodabc }\end{array}$ \\
\hline Beilschmiedia anacardioidesRob. \& Wilcz., Beilschmiedia jacques-felixiiRob. \& Wilcz. & & Seeds & Foodbc, facilitation of childbirthbc \\
\hline Xylopia aethiopica A. Rich. & Plant structures & Stem, leaves & Construction (stem), food (leaves) \\
\hline
\end{tabular}

a: Xylopia aethiopica; b: Beilschmiedia anacardioides; c: Beilschmiedia jacques-felixii.
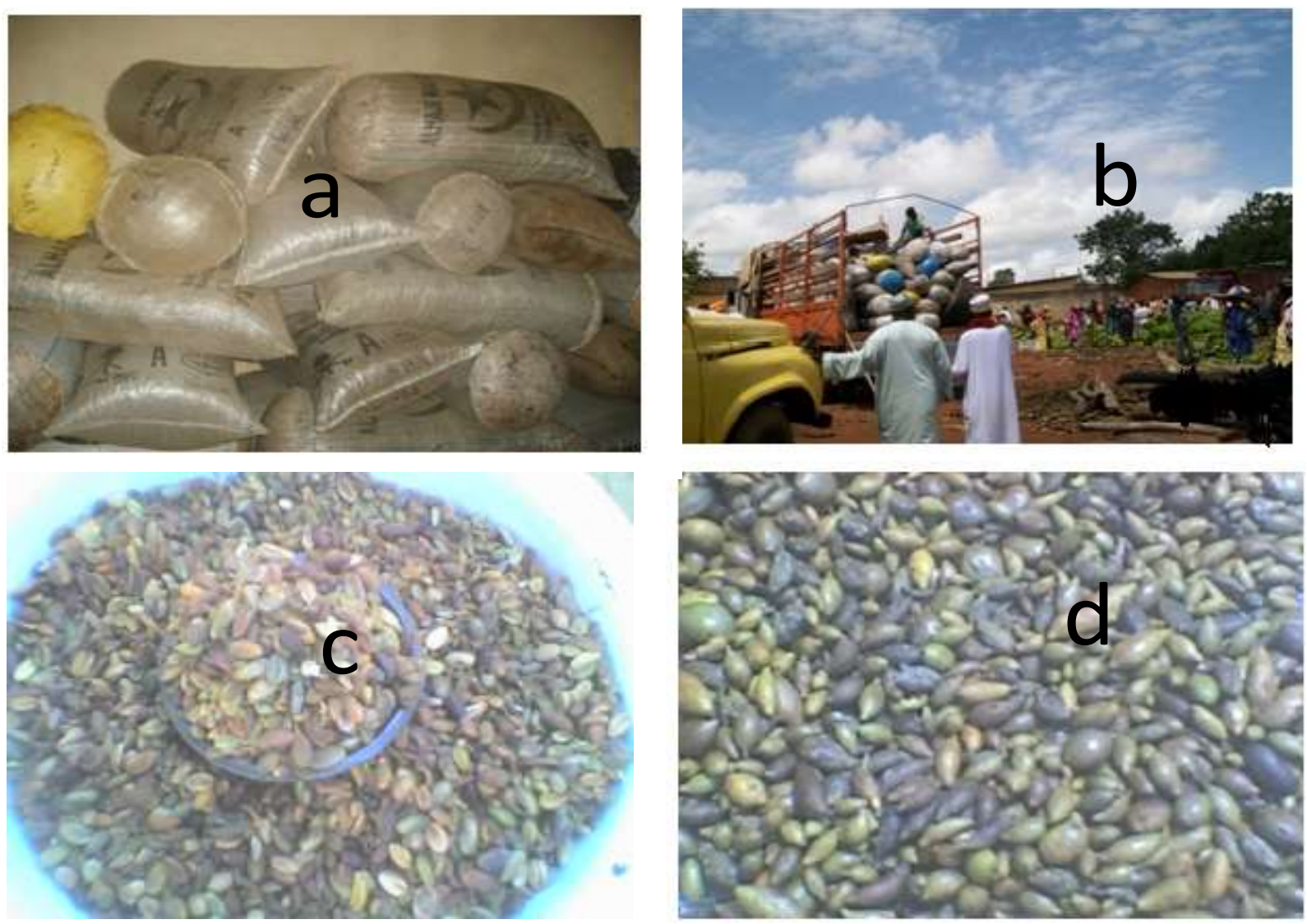

Figure 4. Fruits and seeds of key NTFPs at the periphery of Mbam and Djerem National Park, a) Bags of Xylopia aethiopica fruits stored before exportation, b) Bags of $X$. aethiopica fruits in a lorry for exportation, c) Seeds of Beilschmiedia jacques-felixii in Ngaoundal Market, d) Fruits of $B$. anacardioides in Ngaoundal Market.

costs represented $15 \%$ for $X$. aethiopica and $32 \%$ for $B$.anacardioides and $B$. jacques-feliximwile marketing costs varied from 6 to $25 \%$ for $X$. aethiopica, $B$. anacardioides and $B$. jacques-felixii respectively. The high costs for producers are due to the fact that they pay handling fees, storage fees, transport, communal taxes, forest agents and even traditional rulers. Costs for wholesalers of $X$. aethiopica include mainly custom taxes (flat rate) and transport accounting for $6 \%$.Investigations showed that about $92 \%$ of $X$. aethiopica is marketed and $80 \%$ of $B$. anacardioides and $B$. jacques-felixii is marketed. The other percentages (8 and 20\% respectively) are destined to producers' households, family members and friends. Monthly incomes for producers are above the guaranteed minimum wage in Cameroon (36,270 FCFA). Profit margins of key NTFPs varied from 68 to $85 \%$ for the 69 collectors and from 75 to $94 \%$ for 31 wholesalers.

The main markets of $B$. anacardioides and $B$. jacquesfelixii are Ngaoundal (0.89 t), Tibati $(0.42 \mathrm{t})$ and Pangar $(0.31$ t) which represent 32.96, 15.55 and $11.48 \%$ respectively (Figure 5). Wholesalers obtain more profits 
Table 3. Volumes and sale values of key NTFPs at the periphery of Mbam and Djerem National Park.

\begin{tabular}{|c|c|c|c|c|c|c|c|c|c|c|}
\hline Key NTFPs & $\begin{array}{l}\text { Number of } \\
\text { producers }\end{array}$ & $\begin{array}{l}\text { Volume } \\
(t)\end{array}$ & $\begin{array}{l}\text { Average unit sale } \\
\text { price of producers } \\
\text { (FCFA) }\end{array}$ & $\begin{array}{l}\text { Production } \\
\text { costs* (PC) }^{*}\end{array}$ & $\begin{array}{l}\text { Average unit sale } \\
\text { price of wholesalers }\end{array}$ & $\begin{array}{l}\text { Marketing } \\
\text { costs* (MC) }^{*}\end{array}$ & $\begin{array}{l}\text { Sale value of } \\
\text { producers }\end{array}$ & $\begin{array}{l}\text { Sale value of } \\
\text { wholesalers }\end{array}$ & $\begin{array}{l}\text { Profit margins of } \\
\text { producers (PMP) }\end{array}$ & $\begin{array}{c}\text { Profit margins of } \\
\text { wholesalers (PMW) }\end{array}$ \\
\hline $\begin{array}{l}\text { Beilschmiedia } \\
\text { anacardioides }\end{array}$ & \multirow{2}{*}{17} & 1.023 & $700^{* * *}$ & $229152(32 \%)$ & $1250^{\star \star *}$ & $319688(25 \%)$ & 716100 & $1278750(11)^{\star \star \star *}$ & $486948(68 \%)$ & $959062(75 \%)$ \\
\hline $\begin{array}{l}\text { Beilschmiedia } \\
\text { jacques-felixii }\end{array}$ & & 1.49 & $700^{\star \star *}$ & $333760(32 \%)$ & $850^{\star * *}$ & $316625(25 \%)$ & 1043000 & $1266500(11)^{\star \star \star \star}$ & $709240(68 \%)$ & $949875(75 \%)$ \\
\hline $\begin{array}{l}\text { Xylopia } \\
\text { aethiopica }\end{array}$ & 52 & 172.96 & $10000^{* *}$ & $5520000(15 \%)$ & 15000 & $3312000(6 \%)$ & 36800000 & $55200000(20)^{\star \star \star *}$ & 31280000 (85\%) & 51888000 (94\%) \\
\hline
\end{tabular}

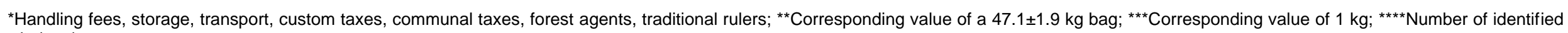
wholesalers.

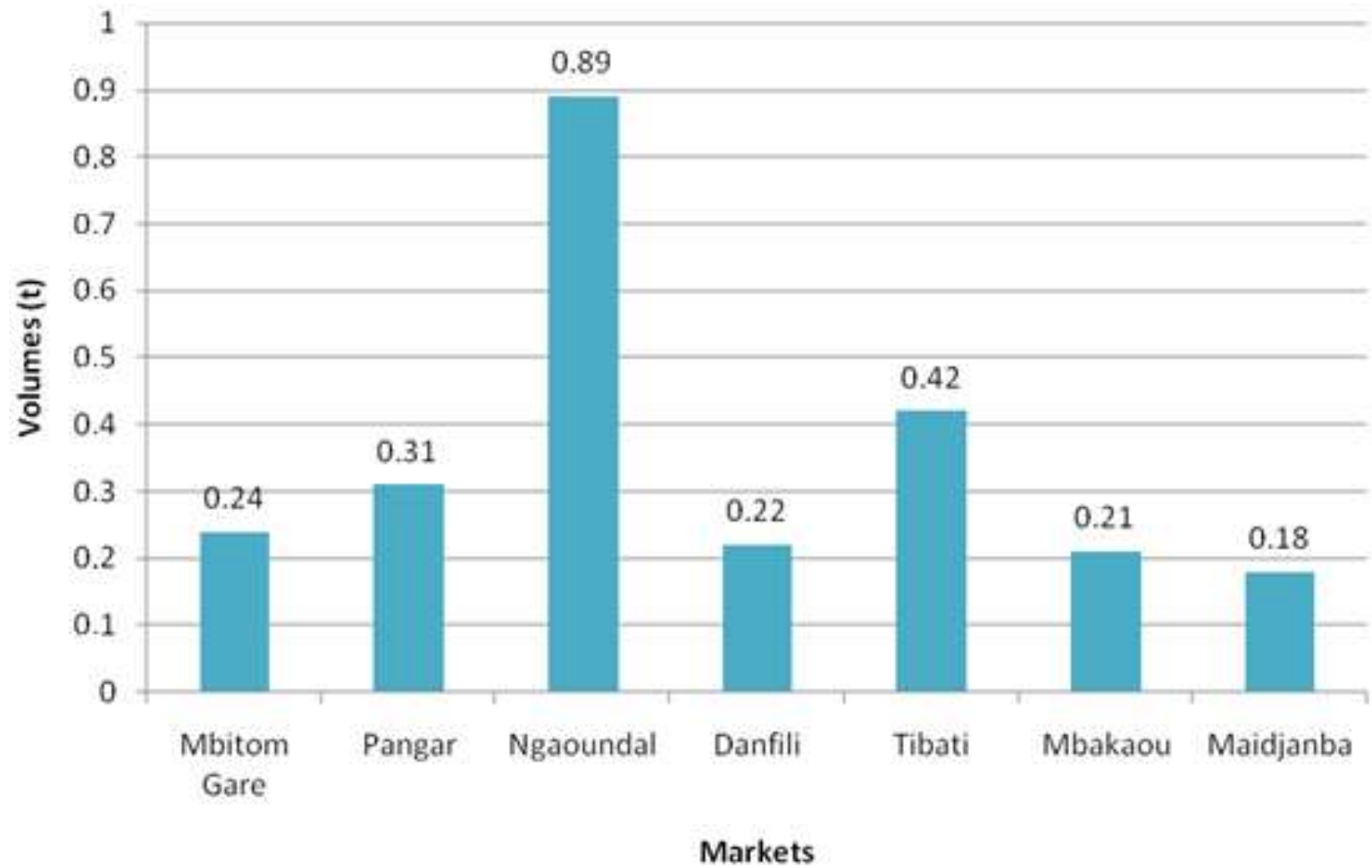

Figure 5. Different markets and volumes of Beilschmiedia anacardioides and B. jacques-felixii fruits. 


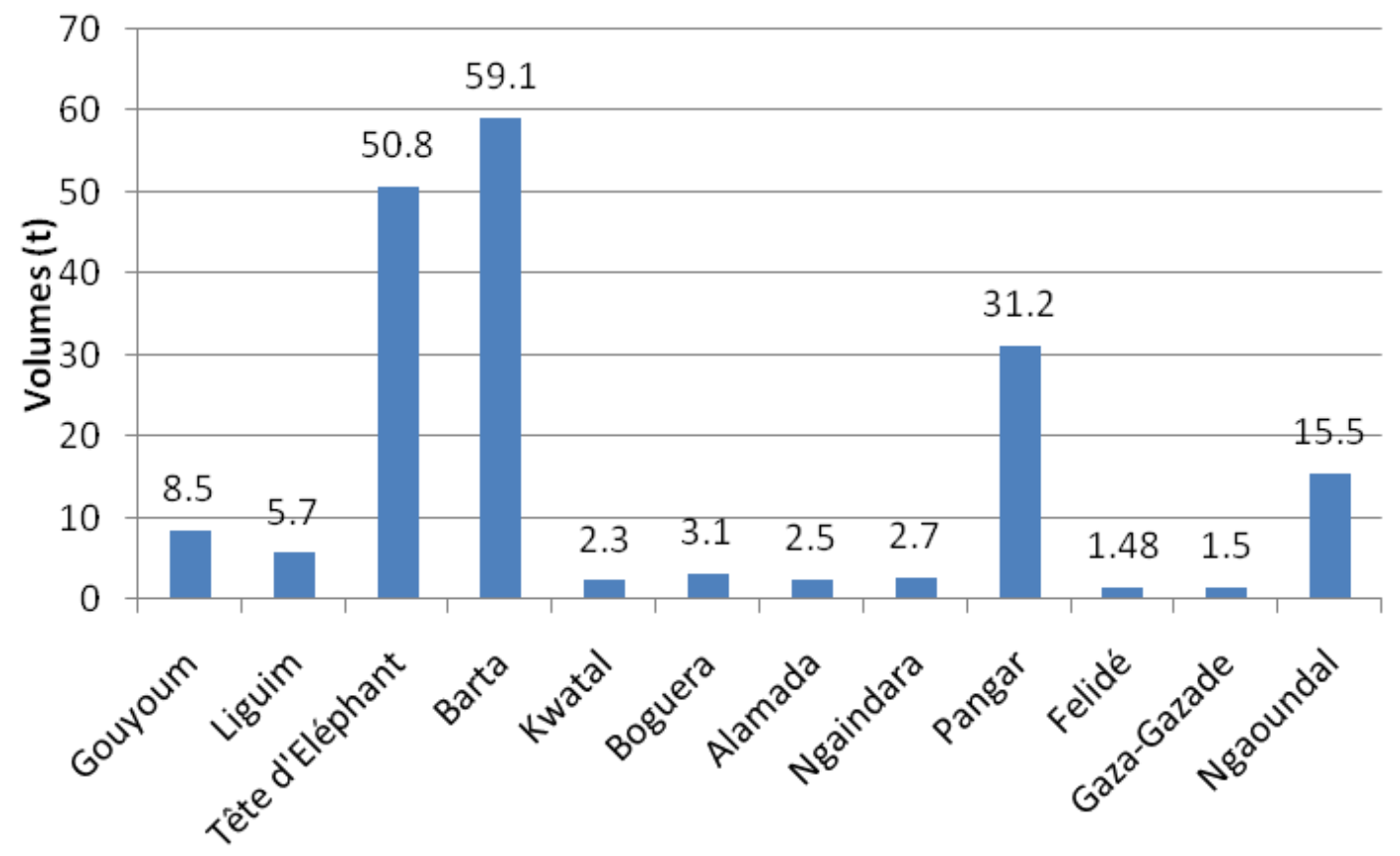

Rayway stations

Figure 6. Different railway stations and volumes of Xylopia aethiopica fruits.

Table 4. Vulnerable status of the three key NTFPs.

\begin{tabular}{lc}
\hline Species & Vulnerable index of the species (Vli) \\
\hline Beilschmiedia anacardioides & 1.87 \\
Beilschmiedia Jacques-felixii & 1.84 \\
Xylopia aethiopia & 2.61 \\
\hline
\end{tabular}

than the collectors ( $\mathrm{t}$-test, $\mathrm{df}=26 ; \mathrm{p}=0.0004$ ). Investigations showed that the retailers are exclusively constituted of women.

Fruits of $X$. aethiopica are gathered in railway stations before being bought by wholesalers who come from Chad, Sudan, Libya and Nigeria.The main railway stations are Mbitom gare (59.1 t), Tête d'Eléphant (50.8 t) and Pangar (31.2 t) accounting for 31.94, 27.45 and $16.86 \%$, respectively (Figure 6 ). Wholesalers have more profits than the collectors (t-test, $d f=70 ; p=0.0009$ ).

\section{Vulnerability status of the three key NTFPs species}

The three key NTFPs perform various vulnerable index: B.jacques-felixii $(\mathrm{VI}=1.84)$; B.anacardioides $(\mathrm{VI}=1.87)$ and $X$. aethiopica $(\mathrm{VI}=2.61)$ (Table 4). B. anacardioides and $B$. jacques-felixii are weakly vulnerable $(\mathrm{VI}<2)$ whereas $X$. aethiopica is highly vulnerable $(\mathrm{VI}>2.5)$. This high vulnerability could be mostly attributed to the exploitation by felling systematically the resource species and its high demand.

\section{DISCUSSION}

Importance of forest resources and related NTFPs around the Mbam and Djerem National Park's ecoregion

The Mbam and Djerem National Park's ecoregion hosts valuable forest resources such as Borassus aethiopum, Calamus deerratus, Canarium schweinfurthii, Ekebergia senegalensis, Laccospermum secundiflorum, Nauclea diderrichii, Nauclea vanderguchtii, Oxytenanthera abyssinica, Parkia bicolor, Pleurotus ostreatus, Ricinodendron heudelotii, Termitomyces aurantiacus, $B$. anacardioides, $B$. Jacques-felixii and $X$. aethiopica. The last three resource species constituted the key three NTFPs of the ecoregion (Souare, 2015). Two categories of product were identified: reproductive organs (fruits, seeds) and plant structures (stem, leaves) (Table 2). All the key species are predominantly used for food and also intervene in the healthcare of local populations who, in majority, resort to the therapeutic heritage. Two reasons 
explain the situation: a low level of purchasing power of consumers, and the expensive costs of pharmaceutical products. Forests significantly contribute to the nutrition and healthcare of local populations. Adekunle and Bakare (2009) argued that in Nigeria, majority of rural households and large proportion of urban households depend on forest products to meet parts of their nutritive needs.In humid zone of Cameroon, Ingram and Schure (2010) indicated that $67 \%$ of key plant products (G. africanum, G. buchholzianum, P. africana, R.heudelotii, Irvingia sp.) are used for food and oils, followed by medicinal products (60\%). This trend was also shown by Falconer (1992) at the periphery of TanoOffin Reserve in Ghana.

\section{Actors' gross and net mean income generation from the three key NTFPs species along the value chain}

$X$. aethiopica, $B$. anacardioides and $B$. jacques-felixiiare of economic importance as they are traded regionally and nationally ( $B$. anacardioides and $B$. jacques-felixii) and internationally ( $X$. aethiopica). They contribute between 68 and $85 \%$ to the households of the producers (Table 3 ). The income obtained enables the local people to meet their basic needs and those of their families such as purchase of medicinal products, kerosene, soap, clothes, construction of houses, and payment of dowry and school fees. This result supports the general observation for some case studies from Africaunderlined by Sunderland and Ndoye (2004) that the contribution to household income is particularly important at times of economic needs such as payment of school fees or provides seasonal income when agricultural labor needs are low, particularly in the rainy season.

$X$. aethiopica is the major plant resource species in the region and accounted for $85 \%$ of income of local people engaged in the trade of plant NTFPs. In comparison to seventeen case studies in Sub-Saharan Africa (Sunderland and Ndoye, 2004), this rate falls above the range of 60 to $78 \%$ where are found the highly valued plant NTFPs. These resource species are Cassiprounea flanaganii $(78 \%)$ in South Africa, $P$. africana $(70 \%)$ in the region of Mount Cameroon, $G$. africanumand $G$. buchholzianum $(62.5 \%)$ in the entire forest region in Cameroon. Angelsen and Babigumira (2010) found that the average regional rate in Central Africa varies between 25 and $40 \%$. Therefore, $X$. aethiopica, $B$. anacardioides and $B$. jacques-felixii make significant contributions to livelihoods and economies, such that if their abundance or supply is jeopardized, it can have measurable repercussions on the well-being of local communities and households. The study reveals also that incomes from plant non-timber forest products vary considerably depending on markets and productsas Angelsen and Babigumira (2010) have stated as regards the contribution of NTFPs in Central Africa.
Social and economic value chain of the three key NTFPs around the Mbam and Djerem National Park's ecoregion

The opportunity to earn significant incomes through nontimber forest products trade depends on economic factors of the product and the ecoregion. These factors concern the quality of the product, the quality of the transformation, the reliability of the production and the existence of competitive products. B.anacardioides, $B$. jacques-felixii and $X$. aethiopica are transformed before their commercialization. $X$. aethiopica fruits are harvested fresh and then dried with fire and in the sun. Dried fruits are packaged in sacks and stored before sale. The seeds of $B$. ancardioides and $B$. jacques-felixii are treated with warm water and dried in the sun. They can be transformed into powder and packaged in plastics before sale.

These practices permit reduction of the post-harvest losses and to increase the shelf life of the products for at least one year. However, collectors are not sufficiently informed of market requirements in terms of quality and quantity of the products. Also, sales of products within the same community are not organized, and the potential of local transformation of the products that can make them more attractive and competitive is weak. Therefore, the more transformation of the products, the higher the contribution of NTFPs to cash income. The survey revealed that the adding value at the level of wholesalers is more important than that of the collectors $(p<0.001)$. Authors in some case studies from Africa (Awono et al., 2009) and in the area of South-East Asia (Wollenberg and Ingles, 1998) demonstrated that when products are accessible and significantly processed locally, costs are low and profit margins are high for harvesters.

\section{Actors' perceptions on the threats on key NTFPs species and implication for value chain sustainability around the study area}

Generally, it has been established that the overall ecological effects, impacts and responses of forest utilization are underpinned by floristic composition, the magnitude or intensity, and the modes and seasons of the harvesting (Arnold and Ruiz Pérez, 2001). The study reveals that the three key resource species of non-timber forest products are exploited for their fruits and seeds. The most common practice for harvesting these organs consists of felling systematically the trees (X. aethiopica). This harmful practice has direct impact on the vital rates, namely the survival of the harvested individuals. Ticktin (2004) demonstrated that even low levels of harvest may result in a significant decline in long-term population growth rates. That is not the case with some tree species that can tolerate very high levels of fruit, seed or flower harvest with little or no decrease in long-term population 
growth rates (Ticktin,2004). For example, it was reported that the estimated sustainable harvest rate for Marula fruits (Sclerocarya birrea subsp. caffra) in South Africa is 92\% (Emanuel et al., 2005).

The extractivism is undertaken at the periphery of the protected area as regards $B$. anacardioides and $B$. jacques-felixii. They are weakly vulnerable $(\mathrm{VI}<2)$, and local people manage the existing individuals in their farms. About $X$. aethiopica with a high vulnerable index $(\mathrm{VI}=2.61)$, harvesting is happening almost near the park, and even in the buffer zone where the resource species are more available.This situation is causing open conflicts between the communities and the forest agents, namely the ecoguards. However, at the north-eastern part of the park, local people have begun to manage the species through enrichment plantings. This can lead in long-term to the goals of conservation of the protected area and the sustainable management of the resource species.

\section{Conclusion}

Non-timber forest products have been widely recognized in Sub-Saharan Africa as a source of significant livelihood value, especially for rural people, since they generate cash incomes, supplementary food and other products required daily. The Mbam and Djerem National Park's ecoregion in Cameroon harbor valuable forest resources, including key non-timber forest products, namely $X$. aethiopica, B. anacardioides and B. jacques-felixii.Market study methods were used to assess the socioeconomic importance of the three plant resource species. Interesting parts of the plants are the fruits that are harvested and processed for sale or local consumption. Annual profit margins for 17 producers of $B$. anacardioides and $B$. jacques-felixii are estimated at 2023.45 USD $(1,196,188$ FCFA) representing 68\%, and for 52 producers of $X$. aethiopica are estimated at 52912.57 USD $(31,280,000$ FCFA) accounting for $85 \%$. This constitutes an important contribution to the total income of producers of these NTFPs across the region. Wholesalers dominate the chains in terms of profit margins and inappropriate standards lead to the exploitation of collectors and inequity in the chain: 11 wholesalers of $B$. anacardioides and $B$. jacques-felixii, 3229.12 USD (1 908937 FCFA) representing 75\% (Ttest, $\mathrm{df}=26 ; \mathrm{p}=0.0004) ; 20$ wholesalers of $X$. aethiopica, 87772.61 USD(51 888000 FCFA) representing 94\% (Ttest, $d f=70 ; p=0.0009)$. The three key NTFPs species record the following vulnerable index: $B$. jacques-felixii $(\mathrm{VI}=1.84) ; B$. anacardioides $(\mathrm{VI}=1.87)$ and $X$. aethiopica $(\mathrm{VI}=2.61)$. Local people are aware of the dangers faced by the high valued species. Their awareness is revealed by the interventionist management through enrichment plantings undertaken in some parts of the periphery of the protected area.

\section{CONFLICT OF INTERESTS}

The authors have not declared any conflict of interests.

\section{ACKNOWLEGEMENTS}

The authors are grateful for the support of International Foundation for Science (IFS) through a grant given to Dr. Souare Konsala ( $\left.N^{\circ} \mathrm{D} / 4979-2\right)$. Special appreciation is particularly extended to Wildlife Conservation Society/Cameroon for the material support and commodities, along with the local communities for their participation, and the reviewers for improvement of the quality of the paper.

\section{REFERENCES}

Angelsen A, Babigumira R (2010). Quantifying the role of forests in poverty alleviation: preliminary results from the PEN dataset. XXIII IUFRO World Congress "Forests for the Future: Sustaining Society and the Environment", IUFRO. Seoul, Korea, 23-28 August 2010.

AdekunleVAJ, Bakare Y(2004). Rural Livelihood Benefits from Participation in Taungya Agroforestry System in Ondo State, Nigeria. Journal of Small-Scale Forest Eco-Management and Policy, pp. 131138.

Arnold JEM, Ruíz-Pérez M(2001). Can non-timber forest products match tropical forest conservation and development objectives? Ecological Economics 39:437-47.

Awono A, Ngono DL, Ndoye O, Tieguhong CJ, Eyebe JP, Tonye $\mathrm{MM}(2002 \mathrm{a})$. Etude sur la commercialisation de quatre produits forestiers non-ligneux dans la zone forestière du Cameroun: Gnetum spp., Ricinodendron heudelotii, Irvingia gabonensis and Prunus africana. FAO, Yaoundé. $96 \mathrm{p}$.

Awono A, Manirakiza D, Ingram V(2009). Etude de base de la filière Gnetum spp. (Fumbwa) dans les Provinces de L'Equateur et de Kinshasa. Etude CIFOR. $82 \mathrm{p}$.

Awono A, Eba'a Atyi R, Foundjem-Tita D, Levang P(2016). Vegetal non-timber forest products in Cameroon, contribution to the national economy. International Forestry Review 18(1):66-77.

Betti JL (2001). Vulnérabilité des plantes utilisées comme antipaludiques dans l'arrondissement de Mintom au sud de la réserve de Biosphère du Dja (Cameroun). Systematics and Geography of Plants 71: 661-678.

Cosyns H, Degrange A, Dewulf R, Van Damme P, Tchoundjeu Z(2011). Can commercialization of NTFPs alleviate poverty? A case study of Ricinodendron heudelotii (Baill.) Pierre ex Pax kernel market in Cameroon. Agricultural Rural Development in the Tropics and Subtropics 112:45-56.

David-Case D (1990). The community as tool box, the idea, methods and tools for participatory assessment, monitoring and evaluation of community forestry. Community Forestry, field manual 2. FAO, Rome $195 \mathrm{p}$.

EmanuelPL, Shackleton CM, Baxter JS. 2005. Modelling the sustainable harvest of Sclerocaryabirrea subsp. caffra fruits in the South African lowveld. Forest Ecological Management 214:91-103.

Endamana D, Angu KA, Akwah GN, Shepherd G, Ntumwel BC (2016). Contribution of non-timber forest products to cash and non-cash income of remote forest communities in Central Africa. International Forestry Review 18(3):280-295.

Falconer J (1992). A study of the Non-timber forest products of Ghana's forest zone. Friends of the Earth, London, pp. 5-135.

Fuashi NA, Popoola L, Mosua IS, Wehmbazeyi NF(2011). Harvesting and marketing of Massularia species in Cameroon and Nigeria. International Journal of Biodiversity and Conservation 3(6):178-184.

Ingram V, Schure J(2010). Review of non-timber forest products in Central Africa: Cameroon, 166p. 
Karki M, Bhattarai N(2006). Streamlining Medicinal Plants Production to Consumption Systems for Improved Livelihoods and Primary Health. Proccedings International Women's Health and Asian Traditional (WHAT).

Letouzey $R(1985)$. Notice de la carte phytogéographique du Cameroun au 1: 500 000. Institut de la carte internationale delavégétation. Toulouse, France, pp. 63-142.

Muhammad SS, Wasonga VO, Syombua MJ, Amnu S, Yazan $A E(2017)$. Non-timber forest products and their contribution to households' income around Falgore Game Reserve in Kano, Nigeria. Ecological Processes 6:23-37.

Scherr SJ,White A, Kaimowitz D(2003). Making markets work for forest communities. International Forestry Review 5:67-73.

Shackleton S, Shackleton C, Shanley P(2011). Non-timber forest products in the global context. Tropical Forestry, Springer. $280 \mathrm{p}$.

Souare K, Amougou A, Biyé EH, Fotso RC(2012). Long-term ecological impacts of harvesting Non-timber Forest Products on tree species diversity at the periphery of Mbam and Djerem National Park. Journal of Ecology and the Natural Environment 4(11):290-302.

Souare K(2015). Gestion intégrée des espèces ressources clés des produits forestiers non-ligneux végétaux au Cameroun: cas de la périphérie du parc national du Mbam et Djerem. Thèse de Doctorat/PhD, Univ. Yaoundé I. 155 p.

SunderlandTCH, Ndoye $\mathrm{O}(2004)$. Forest products, livelihoods and conservation: Case studies of non-timber forest products systems. http://www.cifor.org/publications/pdf_files/Books/NTFPAfrica/TOCChapter6.PDF
Ticktin T (2004). The ecological consequences of harvesting non-timber forest products. Journal of Applied Ecology 41:11-21.

Timko JA, WaeberPO, Kozak RA(2010). The socio-economic contribution of Non-timber Forest Products to rural livelihoods in subSaharan Africa: Knowledge gaps and new directions. International Forestry Review 12:283-294.

Wasseige C, Devers D, Marcken P, Eba'a Atyi R, Nasi R, Mayaux $\mathrm{P}(2009)$. Les forêts du Bassin du Congo. État des forêts 2008. $426 \mathrm{p}$.

WollenbergE, Ingles A(1998). Incomes from the forest: methods for the development and conservation of forest products for local communities. CIFOR, Bogor , 227p. 